\title{
KM1, a Bacteriophage of Clostridium butyricum
}

\author{
By AKIO MAEDA, ${ }^{1} \mathrm{KENJI}$ ISHII, ${ }^{2}$ MAMORU TANAKA, ${ }^{2}$ \\ YUZURU MIKAMI ${ }^{3}$ AND TADASHI ARAI ${ }^{3 *}$ \\ ${ }^{1}$ Nippoh Chemicals Co. Ltd, Research Laboratory, Matsumaru, Isumi-machi, Isumi-gun, \\ Chiba-ken, Japan \\ ${ }^{2}$ Miyarisan Pharmaceutical Co. Ltd, Togura-machi, Hanishina-gun, Nagano-ken, Japan \\ ${ }^{3}$ Department of Antibiotics, Research Institute for Chemobiodynamics, Chiba University, \\ 1-8-1, Inohana, Chiba-shi, Japan
}

(Received 6 January 1986; revised 2 April 1986)

Characteristics of bacteriophage KM1, which infects Clostridium butyricum, are described, and several important properties are compared with those of phage 5, which infects the same species. Phage KM1 has a hexagonal head and a tail with a contractile sheath. Agarose gel electrophoresis patterns of $B g I I I, E c o$ RI and HindIII fragments of the two phage DNAs differed greatly. The $\mathrm{G}+\mathrm{C}$ contents were $30.5 \mathrm{~mol} \%$ for phage $\mathrm{KM} 1$ and $35.4 \mathrm{~mol} \%$ for phage 5 . Among the 32 strains of clostridia tested, phage KM1 infected only $C$. butyricum MII588. Other properties of phage KM1 are also discussed.

\section{INTRODUCTION}

Cowles (1934) isolated a bacteriophage which infected Clostridium tetani, and since then, the properties of phages infecting various species of Clostridium have been reported. The lysis of $C$. butyricum by $C$. saccharoperbutylacetonicum enzymes induced by the phages HM 3 and HM 7 was briefly mentioned by Tahara et al. (1975) and Hongo et al. (1974). In a report concerning phages of $C$. butyricum (Schlechte et al., 1980), phage 5 was used to differentiate two oncolytic strains, $C$. oncolyticum M55 and C. butyricum H8. In this paper, we describe some morphological and physicochemical properties of phage KM1, which lyses C. butyricum MII588 and which is quite different from phage 5.

\section{METHODS}

Phages and bacterial strains. Phage KM1, which infects C. butyricum MII588, was isolated from soil. Phage 5, $C$. oncolyticum M55 (C. butyricum ATCC 13732) and C. butyricum H8 were kindly supplied by Dr H. Schlechte, Zentralinstitut für Krebsforschung der Akademie der Wissenschaften, Berlin-Buch, DDR. C. butyricum MII588 and $C$. oncolyticum M55 were used to prepare each phage lysate. Strains used for the host range test are given in Table 1.

Media. PYG broth, consisting (w/v) of $0.5 \%$ glucose (Wako Pure Chemical Industries), $0.5 \%$ polypeptone (Wako) and $0.3 \%$ yeast extract (Wako), was used for liquid medium. Glucose nutrient agar, consisting (w/v) of $0.5 \%$ glucose (Wako), $1.0 \%$ polypeptone (Wako), $0.5 \%$ meat extract (Wako), $0.3 \% \mathrm{NaCl}, 0.3 \% \mathrm{CaCO}_{3}$ and $1.5 \%$ agar (Wako), was used for solid medium. Glucose nutrient agar without $\mathrm{CaCO}_{3}$ and with $0 \cdot 8 \%(\mathrm{w} / \mathrm{v})$ agar was used for semisolid medium overlays.

Preparation of phage lysates. $\mathrm{CaCO}_{3}(0.5 \%, \mathrm{w} / \mathrm{v})$ was added to an early exponential phase culture of $C$. butyricum MII588 in PYG broth. After 5 min incubation, phage KM1 was added at an m.o.i. of about 0.001 and the culture was incubated at $37^{\circ} \mathrm{C}$ overnight. The culture was centrifuged at $800 \mathrm{~g}$ for $20 \mathrm{~min}$ and the supernate was sterilized by filtration through a $0.45 \mu \mathrm{m}$ Millipore membrane. With $C$. oncolyticum M55, the organism was grown in GAM broth (Nissui Seiyaku), phage 5 was added at an m.o.i. of about 0.001 , and the mixture was incubated at $37^{\circ} \mathrm{C}$ overnight. Phage KM1 was assayed for p.f.u. by the modified double layer method described by Hongo \& Murata (1965).

Electron microscopy. Ammonium sulphate was added to lysates of phage KM1 or phage 5 at a concentration of $280 \mathrm{~g} \mathrm{l}^{-1}$. After overnight incubation at $4{ }^{\circ} \mathrm{C}$, the resultant suspensions were centrifuged at $9000 \mathrm{~g}$ for $30 \mathrm{~min}$. The 
Table 1. Strains of Clostridium used in this study

\begin{tabular}{|c|c|c|c|}
\hline Species & $\begin{array}{c}\text { Strain } \\
\text { no. }^{*}\end{array}$ & Species & $\begin{array}{c}\text { Strain } \\
\text { no.* }\end{array}$ \\
\hline C. butyricum & $\begin{array}{l}\text { MII588† } \\
\text { IAM } 19001 \\
\text { IFO } 3315 \\
\text { IFO } 3858 \\
\text { IAM } 19225 \\
\text { ATCC } 6015 \\
\text { ATCC } 8260 \\
\text { ATCC } 9690 \\
\text { ATCC } 17791 \\
\text { ATCC } 859 \\
\text { ATCC } 860 \\
\text { ATCC } 19398 \\
\text { ATCC } 25779 \\
\text { IAM } 19004 \\
\text { IAM } 19016 \\
\text { H8 } \ddagger\end{array}$ & $\begin{array}{l}\text { C. oncolyticum } \\
\text { C. butylicum\| subsp. convexa } \\
\text { C. beijerinckii } \\
\text { C. pasteurianum } \\
\text { C. acetobutylicum } \\
\text { C. perfringens } \\
\text { C. difficile } \\
\text { C. sporogenes } \\
\text { C. paraputrificum } \\
\text { C. ramosum } \\
\text { C. cadaveris } \\
\text { C. indolis } \\
\text { C. innocuum }\end{array}$ & $\begin{array}{l}\text { M55§ } \\
\text { IAM } 19092 \\
\text { IAM } 19108 \\
\text { ATCC } 25752 \\
\text { ATCC } 6013 \\
\text { IAM } 19012 \\
\text { NCTC } 8237 \\
\text { NCTC } 528 \\
\text { IFM } 2148 \dagger \\
\text { ATCC } 9689 \\
\text { ATCC } 3584 \\
\text { ATCC } 25780 \\
\text { ATCC } 25582 \\
\text { ATCC } 25783 \\
\text { ATCC } 25771 \\
\text { ATCC } 14501\end{array}$ \\
\hline
\end{tabular}

* Sources: IAM, Institute of Applied Microbiology, University of Tokyo, Japan; IFO, Institute of Fermentation, Osaka, Japan; ATCC, American Type Culture Collection, Rockville, Md., USA; NCTC, National Collection of Type Cultures, London, UK.

$\uparrow$ This study.

† Schlechte et al. (1980).

$\S$ C. butyricum ATCC 13732; Schlechte et al. (1980).

|| Matteuzzi et al. (1977).

pellet was dialysed against distilled water, mixed with $2 \%(w / v)$ phosphotungstic acid and placed on 200-mesh Formvar-coated copper grids. Electron micrographs were taken with an H-800 electron microscope (Hitachi Seisakusho).

Host range. The cross-streak method was adopted using lysates of phage KM1 or phage 5 (about $1.0 \times$ $10^{9}$ p.f.u. $\mathrm{ml}^{-1}$ ) and clostridia strains (Table 1) to determine the host range. Plates were incubated at $37^{\circ} \mathrm{C}$ for $48 \mathrm{~h}$.

Isolation of phage DNA. The phage pellet, obtained by ammonium sulphate precipitation as described above, was dialysed at $4{ }^{\circ} \mathrm{C}$ for $7 \mathrm{~h}$ against $0.15 \mathrm{M}$-phosphate buffer $(\mathrm{pH} 7.0)$ containing gelatin $\left(20 \mathrm{mg}^{-1}\right)$. DNAase 1 (Sigma) was added to a final concentration of $1 \mu \mathrm{g} \mathrm{ml}^{-1}$ and the reaction mixture was shaken at $37^{\circ} \mathrm{C}$ for $45 \mathrm{~min}$. The phage pellet was obtained by centrifugation at $100000 \mathrm{~g}$ for $30 \mathrm{~min}$ and was resuspended in $2.0 \mathrm{ml} \mathrm{SSC}$ (standard saline citrate; $0.015 \mathrm{M}$-sodium citrate, $0.15 \mathrm{M}-\mathrm{NaCl}, \mathrm{pH} 7.0)$. A $2.0 \mathrm{ml}$ sample of $100 \%(\mathrm{v} / \mathrm{v}$ ) phenol was added to the suspension and gently shaken at room temperature for $10 \mathrm{~min}$. After centrifugation at $1000 \mathrm{~g}$ for $10 \mathrm{~min}$, the lower phenol layer was removed and the phenol extraction process was repeated. The upper aqueous layer was dialysed against SSC at $4{ }^{\circ} \mathrm{C}$ for $48 \mathrm{~h}$ and stored at $4{ }^{\circ} \mathrm{C}$.

$G+C$ contents of phage DNAs. Melting temperature $\left(T_{\mathrm{m}}\right)$ of phage DNAs in SSC extracted as described above was measured with a Gilford spectrophotometer $2400 \mathrm{~S}$.

Restriction endonuclease digestion. $\lambda$ phage DNA (Sigma) was used as a standard. Restriction endonucleases $B g / I I, E c o$ RI and HindIII were obtained from Boehringer Mannheim, and digestion was done according to the manufacturer's directions.

Agarose gel electrophoresis of DNA fragments. Samples $(20 \mu \mathrm{l})$ of phage DNA or endonuclease-digested phage DNA were mixed with $3 \mu$ l dye solution containing $0 \cdot 175 \%(\mathrm{w} / \mathrm{v})$ bromophenol blue and $60 \%(\mathrm{w} / \mathrm{v})$ sucrose, and were applied to $0.7 \%(\mathrm{w} / \mathrm{v})$ agarose gels. The electrophoresis was done at $110 \mathrm{~V}$ for $2.5 \mathrm{~h}$ in horizontal submarine gels in a buffer ( $\mathrm{pH} 7.9$ ) containing $40 \mathrm{~mm}$-Tris, $5 \mathrm{~mm}$-sodium borate, and $1 \mathrm{mm-EDTA}$. After electrophoresis, the gels were stained with ethidium bromide $\left(0.5 \mu \mathrm{g} \mathrm{ml}^{-1}\right.$ in water) and then photographed under shortwave UV light with a Polaroid type high-speed no. 57 film.

Growth studies of phage-infected strain. A $3 \mathrm{ml}$ sample of PYG broth prepared with $0.067 \mathrm{M}$-phosphate buffer $(\mathrm{pH} 7 \cdot 0$ ) in a $10 \mathrm{ml}$ test tube, was overlaid with $2 \mathrm{ml}$ liquid paraffin. Optical density growth curves of C. butyricum MII588 were recorded at $600 \mathrm{~nm}$. When the $\mathrm{OD}_{600}$ reached $0 \cdot 3$, phage $\mathrm{KM} 1$ was added at an m.o.i. of $1 \cdot 0,0 \cdot 1$ or 0.01 and the $\mathrm{OD}_{600}$ was read at appropriate intervals.

Production of antisera. Two male albino rabbits, each weighing $2 \mathrm{~kg}$, were injected subcutaneously into the dorsum and foot pad with a mixture of $0.2 \mathrm{ml}$ phage KM1 lysate (about $1 \times 10^{6}$ p.f.u. $\mathrm{ml}^{-1}$ ) and $0.2 \mathrm{ml}$ Freund's complete adjuvant, followed by subcutaneous injection into the dorsum with $0.5 \mathrm{ml}$ of the lysate (about $1 \times$ 

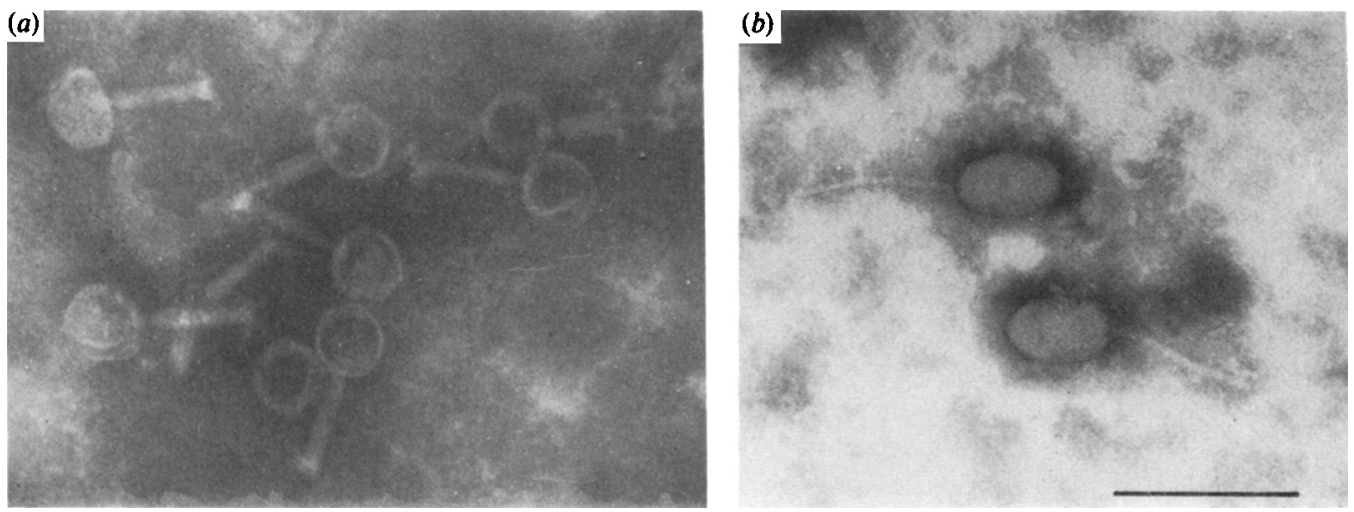

Fig. 1. Electron micrographs of phage KM1 (a) and phage $5(b)$. Bar, $100 \mathrm{~nm}$.

$10^{7}$ p.f.u. $\mathrm{ml}^{-1}$ ) at 4 -d intervals. At 20 and $24 \mathrm{~d}$ after the first injection, $0.8 \mathrm{ml}$ of the lysate (about $1 \times$ $10^{8}$ p.f.u. $\mathrm{ml}^{-1}$ ) was injected via the ear vein; $10 \mathrm{~d}$ after the last injection, the rabbits were bled from the carotid artery. The serum was absorbed with cells of $C$. butyricum MII588, and then inactivated at $56^{\circ} \mathrm{C}$ for $30 \mathrm{~min}$.

Average burst size. A $0.8 \mathrm{ml}$ sample of an exponential phase culture of C. butyricum MII588 $\left(4.2 \times 10^{7} \mathrm{cells}^{-1}\right)$ in nutrient broth was mixed with $0.1 \mathrm{ml}$ phage $\mathrm{KM} 1$ lysate $\left(6.4 \times 10^{8}\right.$ p.f.u. $\left.\mathrm{ml}^{-1}\right)$ and incubated at $37^{\circ} \mathrm{C}$. After $10 \mathrm{~min}, 0 \cdot 1 \mathrm{ml}$ phage $\mathrm{KM} 1$ antiserum was added and after a further $5 \mathrm{~min}$ incubation, $0 \cdot 1 \mathrm{ml}$ of the mixture was added to $9.9 \mathrm{ml}$ nutrient broth and incubated at $37^{\circ} \mathrm{C}$. The samples were assayed for phage after 20,30 and $40 \mathrm{~min}$.

Effect of divalent cations on adsorption and release of phage KM1. By the procedure of Nakajima \& Murooka (1983), $\mathrm{CaCl}_{2}, \mathrm{MgCl}_{2}$, sodium citrate or sodium oxalate was added to nutrient broth desalted with Amberlite IR$120 \mathrm{~B}$. The final concentration of the former two additions was $0.2 \%(\mathrm{w} / \mathrm{v})$ and that of the latter two $0.5 \%(\mathrm{w} / \mathrm{v})$. To $8.9 \mathrm{ml}$ of each broth, $1 \mathrm{ml}$ of an exponential culture of $C$. butyricum MII588 $\left(9.2 \times 10^{6} \mathrm{cells} \mathrm{ml}^{-1}\right)$ and $0.1 \mathrm{ml}$ phage KM1 lysate $\left(9 \cdot 2 \times 10^{6}\right.$ p.f.u. $\left.\mathrm{ml}^{-1}\right)$ were added and incubated at $37^{\circ} \mathrm{C}$. After incubation for $7,15,20,40$ and $60 \mathrm{~min}$, the cultures were centrifuged at $9000 \mathrm{~g}$ for $10 \mathrm{~min}$ and the supernatants were assayed for phage.

Isolation of phage KMI-resistant mutants. Spontaneous phage KM1-resistant mutants of C. butyricum MII588 were selected by mixing $1 \times 10^{6}$ endospores and $1 \times 10^{9}$ phages on plates. After incubation at $37^{\circ} \mathrm{C}$ for $48 \mathrm{~h}$, colonies were picked and purified by three serial single colony isolations.

\section{RESULTS}

Morphology and host range. Typical plaques of phage KM1 after incubation for $48 \mathrm{~h}$ and phage 5 after incubation for $24 \mathrm{~h}$ at $37^{\circ} \mathrm{C}$ were similar, being clear and $1-2 \mathrm{~mm}$ in diameter. Electron microscopy showed phage KM1 particles to have hexagonal heads $60 \mathrm{~nm}$ in diameter and tails with a contractile sheath $90 \mathrm{~nm}$ long. Phage 5 particles have elongated heads measuring $50 \times$ $80 \mathrm{~nm}$ and flexible, sheathless tails $125 \mathrm{~nm}$ long (Fig. 1). Phage KM1 infected only one strain, $C$. butyricum MII588, while phage 5 infected three strains, C. butyricum IAM 19004, C. butyricum $\mathrm{H} 8$ and C. oncolyticum M55 (C. butyricum ATCC 13732).

$G+C$ contents of phage DNAs. The $\mathrm{G}+\mathrm{C}$ contents were $30.5 \mathrm{~mol} \%$ for phage $\mathrm{KM} 1$ and $35 \cdot 4$ mol $\%$ for phage 5 . These values were slightly higher than that of C. butyricum $(27-28 \mathrm{~mol} \%$; Smith \& Hobbs, 1974).

Analysis of phage DNAs by agarose gel electrophoresis. Electrophoresis patterns of DNAs extracted from phages KM1, 5 and $\lambda$ and treated with restriction enzymes $B g I I I, E c o$ RI and HindIII showed marked differences. Phage 5 DNA was not digested by BglII. By comparison with $\lambda$ phage DNA, the $M_{\mathrm{r}}$ both of phage KM1 and of phage 5 DNA was determined to be $31 \times 10^{6}$.

Growth studies of phage-infected strain. Fig. 2 shows lytic curves of cultures infected with phage KM1. Infection at an m.o.i. of $1 \cdot 0$ or $0 \cdot 1$ resulted in a remarkable decrease in OD of about $0 \cdot 2$. 


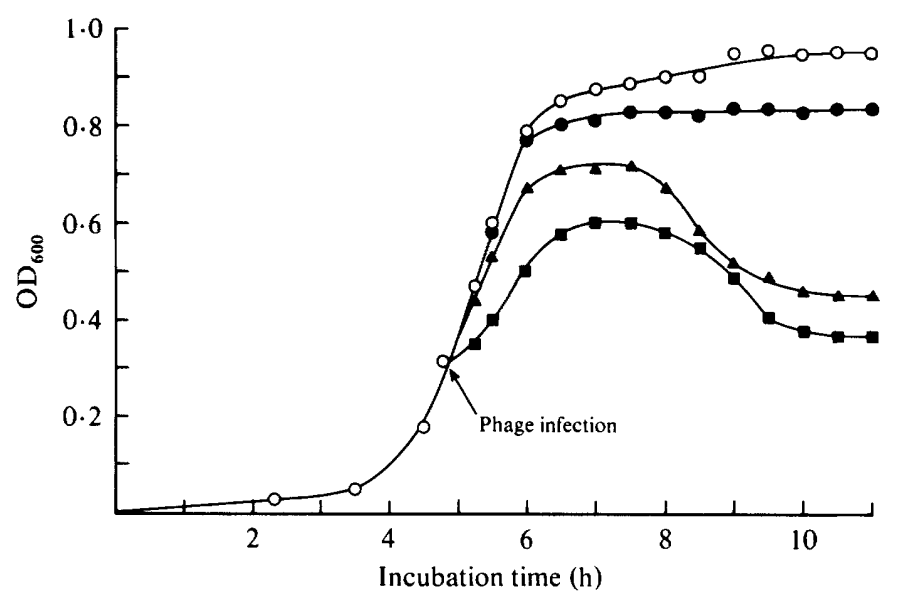

Fig. 2. Lysis of cultures infected with phage KM1. C. butyricum MII588 was infected with phage KM1 at an m.o.i. of $1.0(\square), 0.1(\Delta)$ or $0.01(\mathrm{O})$. Growth curves at $\mathrm{OD}_{600}$ are compared with that of an uninfected control $(\mathrm{O})$.

Average burst size. The change of p.f.u. $\mathrm{ml}^{-1}$ at each incubation time was $8.4 \times 10^{4}$ for $0 \mathrm{~min}$, $9.6 \times 10^{6}$ for $20 \mathrm{~min}$ and $2.6 \times 10^{7}$ for $30 \mathrm{~min}$. At $30 \mathrm{~min}$ after incubation, the burst had almost finished and no further increase of p.f.u. occurred. This data indicated that the average burst size of phage KM1 was about 76.

Effect of divalent cations on adsorption and release of phage $K M 1$. Neither $\mathrm{Mg}^{2+}$ nor $\mathrm{Ca}^{2+}$ had any effect on adsorption of phage KM1. However, in the presence of divalent cations, the phage was released after incubation for $20 \mathrm{~min}$, but without the divalent cations, no release occurred even after $60 \mathrm{~min}$ incubation.

Preparation of phage KMI-resistant mutants. Stable phage KM1-resistant mutants of $C$. butyricum MII588, Res 1, Res 2 and Res 3, were obtained. Their biochemical and physiological properties, such as carbohydrate fermentation, gelatin liquefaction, nitrate reduction and behaviour with milk, were the same as those of the parent strain MII588.

\section{DISCUSSION}

Phage KMl has a hexagonal head and a contractile sheath resembling phage $\alpha 1$, which infects C. botulinum (Kinouchi et al., 1981). In contrast, phage 5 has an elongated head and a flexible, sheathless tail resembling phages which infect $C$. sporogenes (Betz, 1968; Beatriz et al., 1981 ) or several strains of proteolytic types of C. botulinum (Eklund et al., 1969; Dolman \& Chang, 1972).

Among the 32 strains tested (Table 1), only C. butyricum MII588 was lysed by phage KM1. On the other hand, C. oncolyticum M55 (C. butyricum ATCC 13732), C. butyricum H8 and $C$. butyricum IAM 19004 were lysed by phage 5 , and it should be emphasized that all three phage 5-sensitive strains formed rough colonies. C. butyricum ATCC 25779 and C. butyricum IAM 19016 also formed rough colonies, but they were not lysed by phage 5 . The classification of all of these rough strains is doubtful because their cultures contain little butyric acid; they also digest gelatin and casein. When the cultures of C. oncolyticum M55 and C. butyricum IAM 19004 were analysed by steam chromatography, it was found that they produced acetic, propionic, butyric, isobutyric, isovaleric and isocaproic acids. When these two strains were tested for carbohydrate fermentation, they showed positive reactions with cellobiose, fructose, glucose, maltose, sorbitol and sucrose. C. butyricum typically produces smooth colonies (Smith \& Hobbs, 1974), and thus the rough strains are assumed to be atypical. According to these morphological and biochemical characteristics, they might better be classified as $C$. sporogenes. 
Agarose gel electrophoresis of the two phage DNAs digested with endonucleases showed completely different patterns; the two phages lacked DNA homology.

It is known that monovalent cations inactivate phages by the release of phage DNA and the denaturation of phage protein (Hongo \& Ogata, 1969). Hongo et al. (1969) reported inactivation of phage HM 2 with various monovalent cations. However, phage KM1 was not inactivated by $\mathrm{Na}^{+}$or $\mathrm{K}^{+}$under the same conditions. $\mathrm{Ca}^{2+}$ and $\mathrm{Mg}^{2+}$ did not affect the adsorption of phage $\mathrm{KM} 1$ to the host. However, these divalent cations are indispensable for the release of the phage. Shew (1949) reported that $\mathrm{Ca}^{2+}$ was necessary for multiplication of a phage although its host bacteria did not require $\mathrm{Ca}^{2+}$ for growth.

The phage KMl-resistant mutants and the parent strain were treated with $\mathrm{UV}$ and mitomycin $\mathrm{C}$, and no induction of phage $\mathrm{KM} 1$ occurred. This result confirmed that phage $\mathrm{KM} 1$ is a virulent type.

We thank Dr H. Schlechte for supplying us with phage 5, C. oncolyticum M55 and C. butyricum H8.

\section{REFERENCES}

Beatriz, M. N., Francisco, G. \& Francisco, J. C. (1981). Growth inhibition activity and bacteriophage and bacteriocin-like particles associated with different species of Clostridium. Canadian Journal of Microbiology 27, 216-225.

BETZ, J. V. (1968). Some properties of bacteriophages active on the obligate anaerobe Clastridium sporogenes. Virology 36, 9-19.

Cowles, P. B. (1934). A bacteriophage for Cl. tetani. Journal of Bacteriology 27, 163-164.

Dolman, C. E. \& CHANG, E. (1972). Bacteriophages of Clostridium botulinum. Canadian Journal of Microbiology 18, 67-76.

Eklund, M. W., Poysky, F. T. \& Boatman, E. S. (1969). Bacteriophages of Clostridum botulinum types $\mathrm{A}, \mathrm{B}, \mathrm{E}$, and $\mathrm{F}$ and nontoxigenic strains resembling type E. Journal of Virology 3, 270-274.

HoNGo, M. \& MURATA, A. (1965). Bacteriophages of Clostridium saccharoperbutylacetonicum. Part II. Enumeration of phages by the application of the plaque-count technique and some factors influencing the plaque formation. Agricultural and Biological Chemistry 29, 1140-1145.

HoNGo, M. \& Ogata, S. (1969). Bacteriophages of Clostridium saccharoperbutylacetonicum. Part XV. Mechanism of inactivation of HM 2 phage by monovalent cation. Agricultural and Biological Chemistry 33, 488-495.

Hongo, M., Murata, A. \& Ogata, S. (1969). Bacteriophages of Clostridium saccharoperbutylacetonicum. Part XIV. Effect of mono- and divalent cations on HM 2 phage. Agricultural and Biological Chemistry 33, 331-336.
Hongo, M., Tahara, Y. \& Ogata, S. (1974). Purification and properties of phage HM 7-induced lytic enzyme of Clostridium saccharoperbutylacetonicum. Agricultural and Biological Chemistry 38, 755-761.

Kinouchi, T., Taxumi, K. \& Kawata, T. (1981). Characterization of two inducible bacteriophages, $\alpha 1$ and $\alpha 2$, isolated from Clostridium botulinum type A $190 \mathrm{~L}$ and their deoxyribonucleic acids. Microbiology and Immunology 25, 915-927.

MatteuZi, D., Trovatelli, L. D., Biavati, B. \& ZaNi, G. (1977). Clostridia from grana cheese. Journal of Applied Bacteriology 43, 375-382.

NAKaJima, M. \& MUROOKA, H. (1983). Isolation and characterization of nocardiophages for Nocardia sp. Hakkokogaku 61, 1-9.

SCHLeChte, H., MehNert, W.-H., ThIEM, A. \& SCHNEEWEISS, U. (1980). Wirtsbereichstestung von tumorselektiven Clostridium-butyricum-stämmen mit dem phagen 5. Archiv für Geschwulstforschung 50, 53-57.

SHEW, D. I. (1949). Effect of calcium on the development of streptococcal bacteriophages. Nature, London 164, 492-493.

SMITH, L. Ds. \& HoBbs, G. (1974). Genus III. Clostridium Prazmowski 1880, 23. In Bergey's Manual of Determinative Bacteriology, 8th edn, p. 551. Edited by R. E. Buchanan \& N. E. Gibbons. Baltimore: Williams \& Wilkins.

Tahara, Y., Ogata, S. \& Hongo, M. (1975). Properties of phage HM 3-induced lytic enzyme of Clostridium saccharoperbutylacetonicum. Nippon Nogei Kagaku Kaishi 49, 33-38. 